\title{
SUMMIT SURFACES IN BRAZIL
}

\section{AZIZ NACIB AB'SÁBER ${ }^{1}$}

\begin{abstract}
The study of summit planation surfaces and that of inter-plateau planations constitute together one of the most important themes of topographic meso-compartmentation of Brazil. Such planations, on the top of pre-Cambrian terranes, constitute extensive leveling processes of complex structures, later submitted to epeirogenetic uplift of the type called by French authors epirogenese par sacades. In the present work is epitomized the available information on these old planations, usually taken as post-Gondwana - credit is given to pioneer researchers (E.C.Harder and R.T. Chamberlin, E. De Martonne, R. O. de Freitas, F.F.M. de Almeida, Lester King). The study of these planations constitutes a radical transilience from geological history proper into post-Cretaceous geomorphological history of a large part of Brazil.
\end{abstract}

One remarkable fact about Brazilian physiography is the presence of summit surfaces inherited from old planations that acted on parts of Gondwana. In the case of Brazil, the surfaces remaining on the top of plateaus and ridges of resistant rocks constitute benchmarks that facilitate the understanding of the regional and subregional compartmentation of the great Brazilian Plateau. The basic components of the mega-geomorphology of the country include the high plateaus of old terranes subject to successive epeirogenic uplifts and the sedimentary basins nested on the "dorsais" (dorsum) of the old Brazilian platform. The post-Cretaceous uplifts of the Brazilian Shield were accompanied by a synchronic upheaval of the intracratonic Paleo-Mesozoic basins.

Studies on the level summits that exist in different parts of the Brazilian Plateau have had two starting points. The first followed observations made in the mountains of Minas Gerais (Harder \& Chamberlin 1915), where above steep slopes of scarps and mountain ranges old erosion surfaces occur, covered by savanna-like vegetation. Research motivated by the presence of iron ores led to the identification of old planations that succeeded in leveling a whole ensemble of rocks of uneven resistance. The second starting point was derived from a highly significant transect from the Atlantic plateau of Sao Paulo through the marginal lowlands into the western plateaus. Luis Flores de Moraes Rego had already performed a geological section, of great generality, from old granite-gneiss and schist terranes to the axis of the Parana Basin.

But we owe to the great French geomorphologist of the first half of this century - Emmanuel De Martonne - the identification of the main summit surfaces of southeastern Brazil, from the Mantiqueira and Bocaina mountains to the high ridges interposed between the Sao Paulo Basin and the contact belt with the Upper Carboniferous formations exposed on the eastern border of the Parana Basin. In the spirit of the old European geological tradition, De Martonne (1940) assigned to the surfaces he identified classical names, Superficie dos Altos Campos and Superficie das Cristas Medias to the summit surfaces, and Superficie Neogenica to the interplateau surface that cuts into the PermoCarboniferous and partly Triassic terranes in the so called Sao Paulo marginal lowland. He completed the series with a reference to the fossil surface in process of exhumation at the contact between the old pre-Devonian terranes and the Upper Carboniferous formations. Through this geological-geomorphological section published in the Annales de Geographic, in 1941-1942, in the full heat of the Second World War, the French master left a didactic visualization, capable of serving as a standard for other upthrown or downthrown sectors of old Brazilian terranes that occur in the vast territory inherited from the continent of Gondwana. It may be said in passing that later the South African geologist and geomorphologist Lester King (1956), reexamining the problem, ill-advised and ignoring De Martonne's (1940) work, gave new names to the planation surfaces, correctly extending the concepts, however, to other sectors of the Brazilian plateaus.

It is impossible to deal with the question of the summit surfaces without referring to the tectonic behavior of the old shields uplifted by epeirogenesis. In fact, all the evidences of erosion found in uplifted pre-Devonian terranes, on the top of massifs and ranges ${ }^{\wedge}$ constitute documents of broad processes of planation happening approximately at the close of the Cretaceous sedimentation in extra-Amazonian Brazil. Otherwise, in terms of megageomorphology, they are planations inherited from the processes begun in pre-Devonian "oldlands", at the time when the Afro-Brazilian continent still had much continuity. Soon after the gigantic plate tectonics episode that broke apart the two continental blocks, erosive processes continued during the last phases of partial subsidence that happened in sectors of the old Paleo-Mesozoic basins, or that overflowed into late subsiding areas, on the dorsum of the old formations (Parecis, Araripe and Areado, western Bahia and northwestern Minas Gerais).

The main nuclei of summit surfaces in Precambrian Brazilian terranes uplifted after the Late Cretaceous are found on the axes of "dorsais" of shields, from the high plateaus of southeastern Brazil to the level summits of Cola's and Brasilia; and from the Quadrilatero Central Ferrifero of Minas Gerais to the high ridges of the Espinhago and Chapada Diamantina. The junction of the two axes of highlands, remnants of old uplifted planations, is in Minas Gerais, diverging northward (Espinhaço) and discontinuously to the west-northwest. Any map of Brazilian relief, as broad and generic as it may be, cannot fail to stress these two major axes, with their uplifted planation surfaces (surfaces sommitales).

The higher surfaces that occur in sectors of the Brazilian Shield have a special meaning in the discussion of the paleogeography of centro-oriental South America. At the time when Brazil and Africa formed one single "transverse super continent", the former summits of the Afro-Brazilian Shield constituted mega-domes.of old terranes, which behaved as matrices furnishing sediments to the main intracratonic basins. While the regional nuclei of the vast ensemble of pre-Devonian formations leaned towards a persistent positive epeirogenesis, the intracratonic sedimentary basins underwent slow, gradual subsidence.

This discordant behavior of regional nuclei and sedimentary basins caused, during the gigantic tensions that preceded the breakup of the continent, intrusions and magmatic flows over portions of the basins. Meanwhile, ancestral crystalline mega-domes underwent upwarping involving the sectors of shields between the basins. Such warped areas of old granitic-gneissic-schistous structures, rigid and long consolidated, incapable of folding or adjusting to the geological forces in action, became potentially liable to brittle tectonics, from the end of the Cretaceous to the middle of the Tertiary. When the drift forced by plate tectonics was completed, the newly detached Brazilian (or better, Guiano-Brazilian-Patagonian) continent reached approximately its present position, leaving, however, room for Upper Mesozoic and Plio-Miocene geosynclines (pre-Andes and Andes).

In spite of the tectonic vicissitudes that the Brazilian platform underwent since the Devonian, it is certain that the permanently exposed part of the shield was located in the uplands of eastern and central Brazil. The dome of the shield that comprised the continuum Bocaina/Mantiqueira - plus the "dorsais" of the Espinhaco and Canastra-Brasilia - continued eastward, before the South Atlantic existed. After the break up of Gondwana there was an uplift of the remaining half-dome, while discontinuous grabens received thick masses of marine sediments, partially contaminated with fatty, petroleumgenerating elements. The establishment of the Paraiba graben (Taubate Basin) broke locally the continuity of the remaining dome, originating a rift valley. A replica, to a lesser scale, of what happened in East Africa, where brittle tectonics originated the great African rift valley system.

It is easy to understand the sequence of facts that raised the remnants of the centro-oriental plateaus of the Brazilian platform. Shallow Devonian seas transgressed parts of the Afro-Brazilian platform, from the west-southwest in its center-southern part, and from a complementary embayment in the Parnaiba Basin, connected to the Paleozoic Amazonian basin. Next, over the Devonian deposits, during a phase of broader, continuous subsidence, developed the highly hybrid sedimentation of the Late Carboniferous, with glacial, subglacial, glacial-lacustrine and eventually marine sediments. During this phase, when over 1,000 m of glacial and subglacial Gondwana sediments were accumulated, glaciers flowed from the northeast and east of the paleo-dome, showing then low relief and undergoing a continuous process of relative planation. 
After the Late Carboniferous-Permian hiatus, shallow seas in an extensive lacustrine-marine gulf promoted the deposition of mudstones, limestones and sandstones. At this time, at the end of the Paleozoic, shallow seas leveled the basin, while the Africa-Brazil paleo-dome was in a somewhat low tectonic position. Next, in the Late Triassic, there was the establishment of an enormous dune field - of the same type as the present Sahara efrgs - consequent to the establishment of zonal arid climates on the southern edge of Gondwana. Meanwhile the main paleo-dome suffered devastating erosive processes, probably involving a mosaic of rocky stepped ramps. When the tension preceding the plate tectonics mega-event began, pockets of magma formed under the basement of the Parana Basin came up, cutting through the whole pile of Paleo-Mesozoic sediments, in successive flows over the enormous sandy deposits, or filling voids in the strata as diabase sills and lacoliths. Locally the flows accumulated over the extensive dune field reached 13 superimposed structures, hundreds of meters thick. At the end, this pile of lavas, mostly basic ferromagnesian rocks, was raised as a regional sub-dome in eastern-southeastern Santa Catarina and northeastern Rio Grande do Sul. It is an anomalous type of summit area that matches in height the planation surfaces of southeastern Brazil (1,600-1,800 m and 1,100-1200 m). The highest ridges are located in the Sao Joaquim and Palmas altiplano (Santa Catarina); there are, however, broad areas of lower heights on the top of the basalt plateaus, reaching 1,000$1,100 \mathrm{~m}$ in Vacaria and Sao Francisco de Paula (Rio Grande do Sul).

The Borborema Plateau constitutes a peculiar unit among summit planation surfaces; marginal lowlands (depressoes perifericas sertanejas) surround it. At some time the whole belt of crystalline terranes extending from the contact between the Devonian and the basement to the main body of the Borborema (which behaves currently as a central massif of northeastern Brazil) was a shield dome, dipping westward. At present, after episodes of denudation that originated the interplateau sertaneja surfaces, the old dome has become much reduced and outstanding among the surrounding lowlands. From Garanhuns to the Serra do Gigante or the Serra do Teixeira (Pernambuco), there are remnants of post-Cretaceous planation surfaces. In several places the discontinuous summits of the Borborema reach 1,000-1,100 m, but there is a lower level, at $670-700 \mathrm{~m}$. On the heights of the Serra do Martins and Santana in Rio Grande do Norte there is a thin sedimentary formation whose age is disputed, but whose morphogenetic meaning is important to define the age of the Borborema regional macro-dome. It is quite probable that the main core of this old massif originated in two tectonic cycles of upwarping. The first cycle, distinctly post-Cretaceous, clearly Paleogene, and a second one, post-summit sediments of the Serra do Martins, but antecedent to the Barreiras Formation. From which it may be inferred that Borborema reached its features of crystalline macro-dome in relatively recent geologic time (Neogene). This happened independently from the interference of brittle tectonics in some of its borders, especially on the east.

All researchers that have dealt with the mountains and escarpments of the Guyana Plateau are unanimous in saying that post-Cretaceous brittle tectonics has disturbed the study of summit surfaces that may eventually have existed. I share this view, but must say that the Gran Sabana plateau, beyond border monument BV-8, is a typical intermediate summit surface, between 1,000 and 1,250 m. Higher, less continuous but conspicuous summits occur 1,000-1500 $\mathrm{m}$ above this plateau, on the peaks of Roraima and Caboriu. On the mountains of western Roraima, post-tectonic breakage was sufficient to create highs and lows in the relief of the border mountains, masking their features of planation surfaces. However, even around Pico da Neblina, at heights of 2,000-3,000 m, remnants of these surfaces may be identified.

On the top of the Uruguay-Rio Grande do Sul shield there is a characteristic ensemble of summit planations. There is a remaining half-dome turned to the west, northwest and north, on which can be seen the Ca9apava do Sul surface, with an average $450 \mathrm{~m}$. Surrounding, in lower levels, there are inter-plateau surfaces caused by circumdenudation processes, with two levels of Neogene pediplains (surfaces of Campanha Velha and of Campanha Moderna). The difference in height between the Cacapava surface and the Campanha surfaces is only $200-250 \mathrm{~m}$. The leveled summit of the shield has a height two to three times lesser than that of the basaltic plateau at Vacaria and Sao Joaquim. The whole geomorphology of Rio Grande do Sul was shaped by a modest uplift, which raised the Cajapava do Sul surface to approximately $500 \mathrm{~m}$. However, it is important to recognize that the crystalline macro-dome is warped towards the interior (west and southwest) and fractured to the east, towards Lagoa dos Patos and Pelotas Basin. Due to complex features of the regional tectonic evolution, especially the effects of the downthrow of the Torres-Pousadas axis (Leinz 1949), the Uruguay-Rio Grande do Sul shield did not accompany the uplift that took place in southeastern, eastern and central Brazil. Additionally, the age of the summit planation is clearly defined as post-Cretaceous, possibly Paleocene - Oligocene.

From a very broad viewpoint it may be concluded that the most important summit surfaces are located on residual, reworked domes of the old continent of Gondwana. To them may be added the planed areas of "dorsais" of shields (Espinhafo/Diamantina and Bocaina/ Mantiqueira/Brasilia) and the planed summits of the Uruguay-Rio Grande do Sul shield $(450-500 \mathrm{~m})$, the heights of the Serra dos Carajas $(670-700 \mathrm{~m})$ and the Borborema massif $(700-1,150 \mathrm{~m})$, all subject to diverse types of tectonism and broad reworking of ancestral planations.

\section{References}

Ab'Saber, A.N. 1956. Etat actuel des conaissance sur les niveaux d'erosion et les surfaces d'aplanissement au Bresil. In F. Ruellan (Organ.) Premier rapport de la Commission pour I'etude des niveaux d'erosion et les surfaces d'aplanissement autour de I'Atlanticjue, Rio de Janeiro, UGI, Tome V

Ab'Saber, A.N. 1957. O problema das conexoes antigas e da separação da drenagem do Paraiba e Tiête. Boletim Paulista de Geografia, 26:38-49

Ab'Saber, A.N. 1960. Posicão das superficies aplainadas no Planalto Brasileiro. Noticia Geomorfologica, 5:52-54

Ab'Saber, A.N. 1964. 0 relevo brasileiro e seus problemas. In A. de Azevedo (Edit.) Brasil.A terra e o homem. Sao Paulo, Companhia Editora Nacional, Vol. 1, p. 135250

Ab'Saber, A.N. 1965. Da participacdo das depressões periféricas e superficies aplainadas na compartimentação do Planalto Brasileiro. Departamento de Geografia, Faculdade de Filosofia Ciências e Letras - USP, São Paulo, Tese de Livre-Docência

Ab'Saber, A.N. 1966. Superficies aplainadas e terracos na Amazônia. Sao Paulo, Institute de Geografia - USP, 10 p. (Geomorfologia 4)

Ab'Saber, A.N. 1969. Participação das superficies aplainadas nas paisagens do Rio Grande do Sul. São Paulo, Institute de Geografia - USP, 17 p. (Geomorfologia 11)

Ab'Saber, A.N. 1969. Participação das superficies aplainadas nas paisagens do nordeste brasileiro. São Paulo, Institute de Geografia - USP, 38p, (Geomorfologia 19)

Ab'Saber, A.N. 1992. A Serra do Japf: sua origem geomorfológica e a teoria dos refugios. In P. Morellato (Organ.) Historia Natural da Serra do Japi. Sao Paulo, Edit.
Into UNICAMP/FAPESP

Ab'Saber, A.N. 1996. Geomorfologia do Corredor Carajás - São Luis. In: Amazonia: do discurso a praxis, EDUSP, Sao Paulo, p.67-89

Almeida, F.F.M.de 1951. A propósito dos "relevos policiclicos na tectonica do Escudo Brasileiro". Boletim Paulista de Geografia, 9:3-18

Almeida, F.F.M.de 1964. Fundamentos geologicos do relevo paulista. In Institute Geografico e Geologico Geologia do Estado de Sao Paulo, Sao Paulo, IGG, p. 167-263, (IGGBoletim 41)

Barbosa, O. 1959. Quadro provisório das superficies de erosão e aplainamento no Brasil. Noticia Geomorfologica, 4:3|-33

Demangeot, J. 1959. Coordination des surfaces d'erosion du Bresil Oriental. Comptes Rendus, Societe Geologique de France, Paris, n.5, p.99
De Martonne, E. 1940. Problemes morphologiques du Bresil tropical atlantique. Annales de Geographie, 49:1-27 e 106-129. Trad. Revista Brasileira de Geografia, 5:523-550, 6:155-178,1943/1944

Dresch, J. 1957. Les problemes morphologiques du Nord-Est bresilien. Zeitschrift fur Geomorpgologie 1:289-301

Freitas, R.O. 1951. Ensaio sobre o relevo tectonico do Brasil. Revista Brasileira de Geografia 2:171-222

Freitas, R.O. 1951. Relevos policiclicos na tectonica do Escudo Brasileiro. Boletim Paulista de Geografia, 7:3-19

Freitas, R.O. 1953. Ensaio sobre a tectonica moderna do Brasil. Sao Paulo, Faculdade de Filosofia, Ciencias e Letras - USP, 120 p, (Boletim 130 - Geologia 6)

Harder, E.G. \& Chamberlin, R.T. 1915. The geology of central Minas Geraes, Brazil. Journal of Geology 23:341-378, 385-424

James, P.E. 1933. The surface configuration of southeastern Brazil. Annals Association of American Geographers 33:165-193

King, L.C. 1956. A geomorfologia do Brasil Oriental. Revista Brasileira de Geografia 18:186-263

Leinz, V. 1949. Contrihuicao a geologia dos derrames basálticos do Sul do Brasil. SSo Paulo, Faculdade de Filosofia, Ciencias e Letras - USP, 61p, (Boletim C III - Geo-

logia 5) Rio de Janeiro

Rich, J.L 1942. The fuce of South America-an aeral traverse. Washington, Geogaphical J.L. 1942. The face of South America
Society (Special Publication n.26)

Ruellan, F. 1953. O Escudo Brasileiro e os dobramentos defundo. Rio de Janeiro, Faculdade Nacional de Filosofia, Universidade do Brasil (Curso de Especializacao em Geomorfologia)

Ruellan, F. 1956. Premier rapport de la Commission pour ietude des niveaux d'erosion et les surfaces d'aplanissement autour de I'Atlantique. Rio de Janeiro, UGI, 5 tomos

Contribution IGC-032

Received January 31,2000
Accepted for publication April 28, 2000 